\title{
Comparison of different Aethalometer correction schemes and a reference multi-wavelength absorption technique for ambient aerosol data
}

\author{
Jorge Saturno $^{1}$, Christopher Pöhlker ${ }^{1}$, Dario Massabò ${ }^{2}$, Joel Brito ${ }^{3}$, Samara Carbone ${ }^{4}$ Yafang Cheng $^{1}$, \\ Xuguang Chi ${ }^{5}$, Florian Ditas ${ }^{1}$, Isabella Hrabě de Angelis ${ }^{1}$, Daniel Morán-Zuloaga ${ }^{1}$, Mira L. Pöhlker ${ }^{1}$, \\ Luciana V. Rizzo ${ }^{6}$, David Walter ${ }^{1}$, Qiaoqiao Wang ${ }^{1}$, Paulo Artaxo ${ }^{7}$, Paolo Prati ${ }^{2}$, and Meinrat O. Andreae , $^{1,8,9}$ \\ ${ }^{1}$ Biogeochemistry and Multiphase Chemistry Departments, Max Planck Institute for Chemistry, \\ P.O. Box 3060, 55020 Mainz, Germany \\ ${ }^{2}$ Department of Physics \& INFN, University of Genoa, via Dodecaneso 33, 16146, Genoa, Italy \\ ${ }^{3}$ Laboratory for Meteorological Physics, University Blaise Pascal, Clermont-Ferrand, France \\ ${ }^{4}$ Institute of Agrarian Sciences, Federal University of Uberlândia, Uberlândia, Minas Gerais, Brazil \\ ${ }^{5}$ Institute for Climate and Global Change and School of Atmospheric Sciences, Nanjing University, Nanjing, China \\ ${ }^{6}$ Department of Earth and Exact Sciences, Institute of Environmental, Chemical and Pharmaceutics Sciences, \\ Federal University of São Paulo, São Paulo, Brazil \\ ${ }^{7}$ Department of Applied Physics, Institute of Physics, University of São Paulo, Rua do Matão, Travessa R, \\ 187, CEP 05508-900, São Paulo, SP, Brazil \\ ${ }^{8}$ Scripps Institution of Oceanography, University of California San Diego, La Jolla, CA 92098, USA \\ ${ }^{9}$ Geology and Geophysics Department, King Saud University, Riyadh, Saudi Arabia
}

Correspondence to: Jorge Saturno (j.saturno@mpic.de)

Received: 31 October 2016 - Discussion started: 13 December 2016

Revised: 19 February 2017 - Accepted: 12 July 2017 - Published: 9 August 2017

\begin{abstract}
Deriving absorption coefficients from Aethalometer attenuation data requires different corrections to compensate for artifacts related to filter-loading effects, scattering by filter fibers, and scattering by aerosol particles. In this study, two different correction schemes were applied to seven-wavelength Aethalometer data, using multi-angle absorption photometer (MAAP) data as a reference absorption measurement at $637 \mathrm{~nm}$. The compensation algorithms were compared to five-wavelength offline absorption measurements obtained with a multi-wavelength absorbance analyzer (MWAA), which serves as a multiple-wavelength reference measurement. The online measurements took place in the Amazon rainforest, from the wet-to-dry transition season to the dry season (June-September 2014). The mean absorption coefficient (at $637 \mathrm{~nm}$ ) during this period was $1.8 \pm 2.1 \mathrm{Mm}^{-1}$, with a maximum of $15.9 \mathrm{Mm}^{-1}$. Under these conditions, the filter-loading compensation was negligible. One of the correction schemes was found to artificially
\end{abstract}

increase the short-wavelength absorption coefficients. It was found that accounting for the aerosol optical properties in the scattering compensation significantly affects the absorption Ångström exponent $\left(\stackrel{\circ}{A}_{\mathrm{ABS}}\right)$ retrievals. Proper Aethalometer data compensation schemes are crucial to retrieve the correct $\stackrel{\circ}{\mathrm{ABS}}_{\mathrm{AB}}$, which is commonly implemented in brown carbon contribution calculations. Additionally, we found that the wavelength dependence of uncompensated Aethalometer attenuation data significantly correlates with the $\stackrel{\circ}{a}_{\mathrm{ABS}}$ retrieved from offline MWAA measurements.

\section{Introduction}

Aerosol particles scatter and absorb solar radiation in the atmosphere and thus have an important impact on the Earth's radiative budget and climate (Andreae and Ramanathan, 2013; IPCC, 2013; Penner et al., 1992; Yu et al., 2006). 
Light absorption by atmospheric aerosols is dominated by black carbon (BC), an aerosol species that is emitted by incomplete combustion of biomass or fossil fuels (Bond and Bergstrom, 2006). Black carbon absorbs radiation from infrared to near-UV wavelengths and leads to positive radiative forcing (IPCC, 2013). Other light-absorbing aerosols include a class of organics called brown carbon $(\mathrm{BrC})$ (Andreae and Gelencsér, 2006), mineral dust (Myhre and Stordal, 2001), and primary biological aerosol particles (PBAPs) (Després et al., 2012). High uncertainties still remain regarding the aerosol interactions with solar radiation (Andreae and Ramanathan, 2013; Bond et al., 2013), especially because ambient aerosol absorption is often measured over a limited wavelength range or at only one wavelength.

The wavelength dependence of aerosol light absorption is expressed by the absorption Ångström exponent $\left(\stackrel{\circ}{a}_{\mathrm{ABS}}\right)$ (Ångström, 1929). The $\stackrel{\leftrightarrow}{A}_{\mathrm{ABS}}$ of fresh fossil-fuel-derived BC is typically around 1.0 - i.e., the absorption changes as a function of $\lambda^{-1}$ (Bergstrom et al., 2002). However, when BC particle size is larger than $50 \mathrm{~nm}$ or becomes coated by nonabsorbing materials, the $\stackrel{\circ}{A B S}_{\mathrm{ABS}}$ can decrease below 1.0 (Lack and Langridge, 2013). Moreover, the bulk aerosol wavelength dependence can significantly increase in the presence of other light absorbers, such as $\mathrm{BrC}$ (Andreae and Gelencsér, 2006; Kirchstetter et al., 2004), reaching high values between 3.5 and 7.0. Assuming a fixed spectral dependence of 1 for BC, several studies have estimated the BrC contribu-

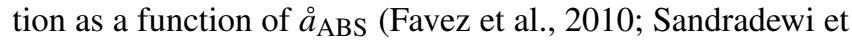
al., 2008). However, given the uncertainties associated with the $\stackrel{\circ}{a B S}_{\mathrm{ABS}}$ of $\mathrm{BC}$, these methods could potentially provide erroneous BrC estimations (Garg et al., 2016; Schuster et al., 2016a, b; Wang et al., 2016).

Absorption coefficients and $\mathrm{BC}$ mass concentrations are related by the mass absorption cross section (MAC) (Bond et al., 2013). Ground-based continuous measurements of BC mass concentrations and absorption coefficients are required to retrieve the appropriate ambient aerosol MAC values, since this relationship and its wavelength dependence are affected by the mixing state and physical and chemical conditions of the aerosol particles (Flowers et al., 2010; Lack and Cappa, 2010; Moosmüller et al., 2011). Moreover, retrieving the wavelength dependence of ambient aerosol optical properties requires absorption measurements at two or more wavelengths.

Only a few commercially available techniques offer multiwavelength absorption measurements. The most commonly used methods are filter-based techniques, including a modified version of the particle soot absorption photometer (PSAP) (Virkkula, 2010; Virkkula et al., 2005), which measures at three different wavelengths in the visible spectral region, and the Aethalometer (Hansen et al., 1984), which measures the attenuation of light at two or seven different wavelengths ( $2 \lambda$ vs. $7 \lambda$ instrument). The above-mentioned instruments are filter-based techniques that determine attenuation and suffer from various artifacts (detailed discussion below), converting attenuation coefficients to absorption coefficients requires several corrections (Arnott et al., 2005; Collaud Coen et al., 2010; Schmid et al., 2006; Virkkula et al., 2007; Weingartner et al., 2003) that generally need concomitant scattering and additional absorption measurements. The correction process of filter-based measurement artifacts introduces uncertainties in the $\stackrel{a}{\mathrm{ABS}}_{\mathrm{ABS}}$ that are difficult to determine (Collaud Coen et al., 2010).

Two well-known artifacts affect filter-based absorption measurements by enhancing or reducing the effective optical path length. One of them is related to the multiple-scattering effects, which induces a positive bias of light attenuation. The multiple-scattering effects are caused by the scattering by the filter fibers and the scattering by aerosol particles on the filter. The scattering by aerosol particles depends on the optical properties and size distribution of the measured aerosol particles. On the other hand, the second effect is related to the shadowing that deposited aerosol particles cause on each other. This effect, called filter-loading effect, reduces the optical path length in the filter and depends on the amount and optical properties of the deposited particles.

The bias related to multiple-scattering effects can be reduced by measuring the radiation reflected by the filter at different angles and simulating the radiation transfer. This principle was incorporated in the design of the multi-angle absorption photometry (MAAP) technique (Petzold and Schönlinner, 2004). The design consists of a single-wavelength instrument (637 nm LED light source) that measures the transmitted radiation through a glass-fiber filter and the reflectance at two different angles $\left(130^{\circ}\right.$ and $\left.165^{\circ}\right)$. Using this configuration and a radiation transfer model, the instrument is able to account for the mentioned artifacts related to multiple scattering and provides approximately "corrected" absorption coefficients (Petzold et al., 2005).

For accurate estimation of absorption coefficients and their spectral dependency, Aethalometer measurements rely on a number of correction procedures; a compilation of different correction schemes can be found in Collaud Coen et al. (2010). The first systematic correction scheme that deals with the different artifacts affecting Aethalometer measurements was proposed by Weingartner et al. (2003). This correction scheme uses a comparison with an indirect light absorption measurement (extinction minus scattering) to estimate a multiple-scattering compensation. In addition, a filterloading correction was estimated by empirically calculating a "shadowing factor". This correction consists of the following empirical equation that converts attenuation coefficients, $\sigma_{\mathrm{ATN}}$, into absorption coefficients, $\sigma_{\mathrm{ap}}$,

$\sigma_{\mathrm{ap}}=\frac{\sigma_{\mathrm{ATN}}}{C \cdot R(\mathrm{ATN})}$,

where $C$ accounts for multiple-scattering effects on the filter, due to (a) scattering by the filter fibers and (b) scattering by aerosol particles embedded on the filter. The factor $R(\mathrm{ATN})$ accounts for the filter-loading effect. 
Later, Virkkula et al. (2007) proposed another filterloading correction through calculating the average attenuation before and after a filter change. This correction applied a compensation factor in the form of $(1+k \times \mathrm{ATN})$, where $k$ is calculated for each filter change and ATN corresponds to the attenuation. A similar approach was used to design the dual-spot technology Aethalometer (model AE33) that intrinsically compensates for filter-loading effects using a two beam system with different flow rates (Drinovec et al., 2015).

In a detailed study, Arnott et al. (2005) introduced a scattering correction factor that accounts for the aerosol particle scattering artifact. In a similar way, Schmid et al. (2006) proposed a correction algorithm that included a parameterization of the scattering by filter fibers and scattering by aerosol particles as a function of $\stackrel{\circ}{\mathrm{ABS}}_{\mathrm{B}}$ and an iteration procedure to obtain corrected absorption coefficients. Both correction schemes used photoacoustic spectroscopy (PAS) measurements at $532 \mathrm{~nm}$ as a reference absorption measurement. Later, by using MAAP absorption measurements as a reference, Collaud Coen et al. (2010) evaluated the abovementioned correction algorithms and proposed two new ones based on the Schmid and Arnott corrections. Their algorithms, among several changes to the previous ones, included a new scattering correction parameterization that uses measured optical properties of the aerosol particles instead of the "standard" ones implemented in Schmid and Arnott correction algorithms. The comparison made by Collaud Coen et al. (2010) resulted in a good agreement between MAAP and Aethalometer BC measurements when using the "Schmidlike" correction algorithm. On the other hand, the "Arnottlike" algorithm lead to many negative $\sigma_{\mathrm{ap}}$ values, especially under low absorption conditions (Collaud Coen et al., 2010).

Previous studies on Aethalometer compensation schemes have evaluated corrected absorption coefficients in comparison to reference absorption measurements (PAS or MAAP), which were done at only one wavelength. In this study, we use a multi-wavelength absorbance analyzer (MWAA), introduced by Massabò et al. (2013, 2015), to conduct a systematic multi-wavelength evaluation of ambient data. This way we can estimate the impact of the most common and reliable Aethalometer correction schemes on the $\stackrel{\circ}{a}_{\mathrm{ABS}}$ uncertainties. We used collected MAAP filter samples from longterm aerosol measurements in central Amazonia to perform offline multi-wavelength absorption measurements using the MWAA. The results presented here are relevant for the study of valuable multi-wavelength data provided by the widely used Aethalometers.

\section{Materials and methods}

\subsection{Sampling site and selected data period}

Field measurements were carried out at the Amazon Tall Tower Observatory (ATTO) $\left(08.602^{\prime} 02^{\circ} \mathrm{S}, 00.033^{\prime} 59^{\circ} \mathrm{W}\right)$, located in the Uatumã Sustainable Development Reserve, Amazonas State, Brazil, in the central Amazon Basin. The site is located $150 \mathrm{~km} \mathrm{NE}$ of the city of Manaus, upwind of the urban plume. A detailed description of the site can be found in Andreae et al. (2015).

The atmospheric aerosol was collected by using a $60 \mathrm{~m}$ long, 1 in. diameter stainless steel inlet tube without size cutoff, installed on a triangular mast since early 2014 . The laminar flow rate in the inlet was constant at $30 \mathrm{~L} \mathrm{~min}^{-1}$. The aerosol stream relative humidity was decreased down to 30 $40 \%$ by using diffusion driers. In this study, we corrected the data for standard temperature and pressure $(273.15 \mathrm{~K}$ and $1013.25 \mathrm{hPa}$ ) and did not apply any correction to compensate for particle losses. The sampling period analyzed here comprises the wet-to-dry transition time (June-July 2014) and part of the dry season (August-September 2014). In the beginning of the measurement period (beginning of June), aerosol particle number concentrations were very low, in the order of $100-400 \mathrm{~cm}^{-3}$, measured by a condensation particle counter (CPC) (Andreae et al., 2015). These typical wetseason conditions slightly changed during the transition season until the end of August, when particle number concentrations increased to around $500-2000 \mathrm{~cm}^{-3}$ (Andreae et al., 2015). The selected measurement period was a good opportunity to evaluate the Aethalometer performance under different conditions. During this period, the aerosol absorption coefficients increased from near detection limit values to the highest values measured at the ATTO site during the dry season.

\subsection{Instrumentation}

A $7 \lambda$ Aethalometer (model AE31, Magee Scientific Company, Berkeley, USA; nominal wavelengths: $370,470,520$, $590,660,880$, and $950 \mathrm{~nm}$ ) was used to measure attenuation coefficients $\sigma_{\mathrm{ATN}}$, which are reported by the instrument as equivalent black carbon $\left(\mathrm{BC}_{\mathrm{e}}\right)$ mass concentrations. Details about the measurement principle and the different corrections to the data are explained in the next section.

Scattering coefficients, $\sigma_{\mathrm{sp}}$, were measured by a $3 \lambda$ nephelometer (model Aurora 3000, Ecotech Pty Ltd., Knoxfield, Australia; nominal wavelengths: 450, 525, and $635 \mathrm{~nm}$ ). The instrument was manually calibrated using $\mathrm{CO}_{2}$ as span gas. Zero tests and spans were conducted periodically. The scattering coefficients measured by the instrument were corrected for truncation errors following the method proposed by Müller et al. (2011), using the sub-micrometer correction factors as function of the scattering Ångström exponents. The detection limits, calculated as 3 standard deviations of $1 \mathrm{~min}$ resolution particle-free air measurements, were 1.1, 0.9, and $0.7 \mathrm{Mm}^{-1}$ at 450,525 , and $635 \mathrm{~nm}$, respectively. Due to a malfunction of the $635 \mathrm{~nm}$ channel, we excluded those data from our calculations.

A multi-angle absorption photometer, MAAP (model 5012, Thermo Electron Group, Waltham, USA) 
was used to measure the absorption coefficient at $637 \mathrm{~nm}$. The instrument uses a glass-fiber filter tape, where the aerosol particles are collected on a sample spot. Light transmission $\left(\right.$ at $\left.0^{\circ}\right)$ and reflectance at two different angles $\left(130^{\circ}\right.$ and $165^{\circ}$ ) are measured every $5 \mathrm{~min}$ (Petzold et al., 2005). A radiative model calculation provides the light absorption coefficient derived from the absorbance measurements and accounts for the light scattering by filter fibers and aerosol particles deposited on the filter. The instrument reports $\mathrm{BC}_{\mathrm{e}}$ mass concentrations calculated by assuming a mass absorption cross section (MAC) of $6.6 \mathrm{~m}^{2} \mathrm{~g}^{-1}$, based on Bond et al. (2006). A measurement bias after every filter change can occur if the absorption coefficients exceed $\sim 20 \mathrm{Mm}^{-1}$ (Hyvärinen et al., 2013), which was not the case during the period of this study. The instrument sampled at a flow rate of $500 \mathrm{Lh}^{-1}$ in series with the nephelometer and was configured to trigger a filter change when transmission reached a minimum of $60 \%$ or after $24 \mathrm{~h}$. Therefore, more samples were collected during the dry season, when the aerosol particle concentration was higher and the transmission threshold was reached quickly. All data obtained from the online measurements (nephelometer, Aethalometer, and MAAP) were aggregated to $30 \mathrm{~min}$ means. MAAP data below the detection limit $\left(0.132 \mathrm{Mm}^{-1}\right.$ with $30 \mathrm{~min}$ resolution) were excluded from the analysis.

The MWAA was used to measure the light absorption coefficients on MAAP-collected filter samples. This instrument was developed by Massabò et al. (2013) and measures the light transmitted through a filter sample (forward hemisphere) and the light reflected at two different angles (backward hemisphere) in a similar configuration to the MAAP. By using a radiative transfer model, the light absorption coefficients can be calculated. The instrument design offers the advantage of accounting for the multiple-scattering effects and is able to measure absorption coefficients at three different wavelengths, as initially introduced, and was later upgraded to measure at five different wavelengths $(375,407,532,635$, and $850 \mathrm{~nm}$ ) (Massabò et al., 2015). The MAAP aerosolladen filter tape was collected at the ATTO site and analyzed by MWAA at the University of Genoa, Genoa, Italy. During transport of the samples, they could be affected by aging of the organic aerosol, microbial processes, and/or loss of semivolatile material (Laskin et al., 2015; Saleh et al., 2014). In order to avoid these issues, the samples were collected everyday directly from the MAAP and kept frozen $\left(-4{ }^{\circ} \mathrm{C}\right)$ during the campaign time and transported in a cool bag with blue ice $(\sim 72 \mathrm{~h})$ to the laboratory in Genoa. We reanalyzed some samples after they were stored at room temperature during 3 days to investigate the potential aging of carbonaceous material collected on the filters and found no significant differences in the absorbance results measured by the MWAA.

\subsection{Aethalometer measurements and corrections}

The Aethalometer continuously measures light attenuation on an aerosol-laden filter. The attenuation is defined, according to the Lambert-Beer law, as

$\mathrm{ATN}=-100 \cdot \ln \left(\frac{I}{I_{0}}\right)$,

where $I$ and $I_{0}$ are the light intensity transmitted through an aerosol loaded and an original area of the filter tape, respectively. A list of symbols and abbreviations is provided in Table 1. The instrument is programmed to calculate the $\mathrm{BC}_{\mathrm{e}}$ mass concentration by assuming that a change in attenuation $(\triangle \mathrm{ATN})$ is caused by an increase in the BC mass deposited on the filter substrate during an interval $\Delta t(\mathrm{~min})$, as follows:

$\mathrm{BC}\left(\mathrm{ng} \mathrm{m}^{-3}\right)=\frac{A \cdot \Delta \mathrm{ATN}}{\alpha_{\mathrm{ATN}} \cdot Q \cdot \Delta t}$,

where $A$ is the filter area $\left(1.67 \mathrm{~cm}^{2}\right), \alpha_{\mathrm{ATN}}$ is the $\lambda$-dependent $\mathrm{BC}$ mass attenuation cross section $\left(14625 \mathrm{~nm} \mathrm{~m}^{2} \mathrm{~g}^{-1} \lambda^{-1}\right)$, and $Q$ is the volumetric flow rate in $\mathrm{L} \mathrm{min}^{-1}$. By using the $\alpha_{\text {ATN }}$ recommended by the manufacturer, we reversed the calculation to convert reported mass concentrations back to attenuation coefficients, as

$\sigma_{\mathrm{ATN}}=\mathrm{BC}\left(\mathrm{ng} \mathrm{m}^{-3}\right) \cdot \alpha_{\mathrm{ATN}}$.

Two different correction schemes were applied to our dataset, including the Schmid et al. (2006) and the Collaud Coen et al. (2010) algorithms. These two correction schemes were chosen because both of them compensate for the three artifacts that affect Aethalometer measurements. The Arnott and Collaud Coen's Arnott-like corrections were excluded due to their limitations when dealing with low-absorption data. Both the Collaud Coen and the Schmid correction require concomitant scattering measurements and a reference absorption measurement, which in our case was the MAAP. Moreover, we present and discuss a comparison of corrected Aethalometer data to the multi-wavelength light absorption measurement obtained from the MWAA.

\subsubsection{Schmid correction algorithm}

The Schmid correction consists of an iterative procedure, which is applied to each measured attenuation spectrum. The compensated absorption coefficients, $\sigma_{\mathrm{ap}}$, are calculated from attenuation coefficients, $\sigma_{\mathrm{ATN}}$, by accounting for the different artifacts,

$$
\begin{aligned}
\sigma_{\mathrm{ap}} & =\frac{\sigma_{\mathrm{ATN}}}{\left(C_{\mathrm{ref}}+C_{\mathrm{sca}}\right) \cdot R} \\
& =\frac{\sigma_{\mathrm{ATN}}}{\left(C_{\mathrm{ref}}+m_{\mathrm{s}} \frac{\omega_{0}}{1-\omega_{0}}\right)\left[\left(\frac{1}{f}-1\right)\left(\frac{\ln \mathrm{ATN}-\ln 10}{\ln 50-\ln 10}\right)+1\right]},
\end{aligned}
$$

where $C_{\text {ref }}$ compensates for the scattering effects in comparison with a reference absorption measurement, $C_{\mathrm{sca}}$ accounts 
Table 1. List of symbols and abbreviations used.

\begin{tabular}{|c|c|c|c|}
\hline Description & Abbreviation & Symbol & Units \\
\hline \multicolumn{4}{|l|}{ Instruments } \\
\hline Aethalometer & $\mathrm{AE}$ & & \\
\hline Multi-angle absorption photometer & MAAP & & \\
\hline Multi-wavelength absorbance analyzer & MWAA & & \\
\hline \multicolumn{4}{|l|}{ Parameters } \\
\hline Attenuation & ATN & ATN & \multirow{15}{*}{$\begin{array}{l}\mathrm{m}^{-1} \\
\mathrm{~m}^{-1} \\
\mathrm{~m}^{-1} \\
\mathrm{~m}^{2} \mathrm{~g}^{-1} \\
\mathrm{~m}^{2} \mathrm{~g}^{-1} \\
\mathrm{~m}^{-1}\end{array}$} \\
\hline Absorption Ångström exponent & AAE & $\stackrel{\circ}{a} \mathrm{ABS}$ & \\
\hline Scattering Ångström exponent & SAE & $\stackrel{\circ}{\mathrm{SCA}}$ & \\
\hline Attenuation Ångström exponent & & $\stackrel{\circ}{a} \mathrm{ATN}$ & \\
\hline Attenuation coefficient & & $\sigma_{\mathrm{ATN}}$ & \\
\hline Absorption coefficient & & $\sigma_{\mathrm{ap}}$ & \\
\hline Scattering coefficient & & $\sigma_{\mathrm{sp}}$ & \\
\hline Mass attenuation cross section & & $\alpha_{\mathrm{ATN}}$ & \\
\hline Mass absorption cross section & MAC & $\alpha_{\mathrm{ABS}}$ & \\
\hline Scattering proportionality constant & & $\beta_{\mathrm{SCA}}$ & \\
\hline Filter-loading correction factor & & $R$ & \\
\hline Shadowing factor & & $f$ & \\
\hline Multiple scattering correction factor & & $C_{\text {ref }}$ & \\
\hline Scattering correction factor & & $C_{\text {sca }}$ & \\
\hline Scattering effect parameter & & $m_{\mathrm{s}}$ & \\
\hline
\end{tabular}

for the scattering effect of non-absorbing aerosol particles and $R$, for the filter-loading effect. The Schmid formulation uses the scattering factor $m_{\mathrm{s}}$ and $\omega_{0}$ to calculate $C_{\text {sca }}$ and the filter loading correction proposed by Weingartner et al. (2003), which takes ATN $=10 \%$ as a reference point and includes the shadowing factor parameter, $f$, which describes the slope between $\sigma_{\mathrm{ATN}}$ and $\ln (\mathrm{ATN})$.

As a first step, $C_{\text {ref }}$ is calculated for attenuation coefficients corresponding to attenuation values lower than $10 \%$, when the filter-loading correction is considered negligible (ATN $<10 \% ; R \approx 1$ ). By using MAAP absorption coefficient measurements, it is possible to obtain $C_{\text {ref }}$ as follows:

$C_{\text {ref }}=\frac{\sigma_{\mathrm{ATN}, 10}}{\sigma_{\mathrm{MAAP}}}$

where $\sigma_{\text {MAAP }}$ is the absorption coefficient measured by the MAAP at $637 \mathrm{~nm}$ and $\sigma_{\mathrm{ATN}, 10}$ is the attenuation coefficient at $637 \mathrm{~nm}$ when $\mathrm{ATN}<10 \%$.

Attenuation coefficients at $590 \mathrm{~nm}$ were interpolated to $637 \mathrm{~nm}$ assuming a power-law relationship as,

$\sigma_{\mathrm{ATN}}(637 \mathrm{~nm})=\sigma_{\mathrm{ATN}}(590 \mathrm{~nm}) \cdot\left(\frac{637 \mathrm{~nm}}{590 \mathrm{~nm}}\right)^{-\mathrm{a}_{\mathrm{ATN}}}$.

The attenuation Ångström exponent $\stackrel{\circ}{a}_{\text {ATN }}$ used in this step was calculated by applying a $\log -\log$ fit to $\sigma_{\text {ATN }}$ vs. $\lambda$, where $\stackrel{\circ}{A T N}_{\text {ATN }}$ was obtained from the slope as follows:

$\ln \sigma_{\mathrm{ATN}}=-\AA_{\mathrm{ATN}} \ln (\lambda)+\ln ($ constant $)$.
Absorption Ångström exponents ( $\left.\stackrel{\circ}{\mathrm{ABS}}_{\mathrm{AB}}\right)$ were obtained in a similar way in further calculations.

The multiple-scattering correction factor, $C_{\text {ref }}$, obtained from Eq. (6) was averaged over the sampling period to calculate the measured filter-loading correction factor, $R_{\text {meas }}$, as

$R_{\text {meas }}=\frac{\sigma_{\mathrm{ATN}}}{\sigma_{\mathrm{MAAP}} \cdot \bar{C}_{\mathrm{ref}}}$.

Weingartner et al. (2003) found that the linear relationship between $\sigma_{\text {ATN }}$ and $\ln (\mathrm{ATN})$ can be used to parameterize the filter-loading effect. The slope of this relationship was given by the shadowing factor parameter, $f$. By applying a linear fit to the $R_{\text {meas }}$ values obtained from Eq. (9) and the attenuation data, as shown in Eq. (10), the term $(1 / f-1)$ can be obtained from the slope.

$R=\left(\frac{1}{f}-1\right)\left(\frac{\ln \mathrm{ATN}-\ln 10}{\ln 50-\ln 10}\right)+1$

Assuming $f$ is wavelength-independent, the averaged $f$ is then used to calculate $R$ at different wavelengths.

In the next step, $C$, understood as the overall multiplescattering correction factor $\left(C_{\text {ref }}+C_{\text {sca }}\right)$, is parameterized as a function of $\lambda$. The single-scattering albedo, $\omega_{0}$, at $637 \mathrm{~nm}$ is used in the following equation to calculate $C$ as

$C=C^{*}+m_{\mathrm{s}} \frac{\omega_{0}}{1-\omega_{0}}$,

where $C^{*}$ corresponds to the multiple-scattering effect by filter fibers and $m_{\mathrm{s}}$ to the aerosol scattering factor found 
by Arnott et al. (2005) (see Table S1). The implemented approach is useful to examine any wavelength dependence on $C$. The values of $\omega_{0}$ were interpolated to the different Aethalometer wavelengths by using the Eq. (12), assuming that absorption and scattering coefficients follow a powerlaw wavelength dependence described by $\stackrel{\circ}{\mathrm{ABS}}_{\mathrm{AB}}$ and $\stackrel{\circ}{\mathrm{SCA}} \mathrm{A}_{\mathrm{S}}$, respectively.

$$
\begin{aligned}
\omega_{0}(\lambda) & =\frac{\sigma_{\mathrm{sp}}}{\sigma_{\mathrm{sp}}+\sigma_{\mathrm{ap}}} \\
& =\frac{\omega_{0, \mathrm{ref}}\left(\frac{\lambda}{\lambda_{\text {ref }}}\right)^{-\mathrm{a} \mathrm{SCA}}}{\omega_{0, \text { ref }}\left(\frac{\lambda}{\lambda_{\text {ref }}}\right)^{-\mathrm{a} \mathrm{SCA}}+\left(1-\omega_{0, \text { ref }}\right)\left(\frac{\lambda}{\lambda_{\text {ref }}}\right)^{-\mathrm{a}_{\mathrm{ABS}}}}
\end{aligned}
$$

Different $\stackrel{\circ}{A}_{\mathrm{ABS}}$ values $(1 ; 1.25 ; 1.5 ; 1.75 ; 2)$ are then used to generate different correlation factors between $\ln (C)$ vs. $\ln (\lambda)$. The coefficients resulting from a quadratic fit are used to parameterize $C$ as a function of $\stackrel{\circ}{A B S}_{\mathrm{ABS}}$ (see Fig. 4 in Schmid et al., 2006). An iteration procedure is used to force the convergence of $\stackrel{\circ}{A}_{\mathrm{ABS}}$. In our calculations, the data converged after seven iterations.

\subsubsection{Collaud Coen correction algorithm}

In this study we implemented the Collaud Coen correction algorithm that resembles the Schmid correction (see Eq. 14b in Collaud Coen et al., 2010). This algorithm is different from the original Schmid algorithm in the calculations of the filterloading effect and the multiple-scattering correction factor. As shown in Eq. (6), the Schmid algorithm filters the data for $\mathrm{ATN}<10 \%$ in order to account only for the scattering by filter fibers in the $C_{\text {ref }}$ calculation. On the other hand, the Collaud Coen algorithm applies a prior filter-loading correction and then, by dividing the reference absorption data (MAAP) by the Aethalometer attenuation coefficients, $C_{\text {ref }}$ is obtained, which accounts for both scattering by filter fibers and scattering by embedded aerosol particles.

Regarding the filter-loading effect, Collaud Coen et al. used the linear dependency of the shadowing factor, $f$, on the single-scattering albedo, $\omega_{0}$, expressed by Eq. (12), to calculate $f$ using measured $\omega_{0}$ and assuming $m$ was constant $(m=0.74)$.

$f=m \cdot\left(1-\omega_{0}\right)+1$

Additionally, they found statistically better results by correlating $\sigma_{\mathrm{ATN}}$ vs. ATN, instead of the logarithmic correlation proposed by Weingartner et al. (2003), which was implemented by Schmid et al. (2010). Considering no filterloading artifact for $\mathrm{ATN}=0$, they proposed the following equation, which replaces Eq. (10):

$R=\left(\frac{1}{m\left(1-\bar{\omega}_{0}\right)+1}-1\right)\left(\frac{\mathrm{ATN}}{50}\right)+1$.

In this case, $\omega_{0}$ was averaged for every filter spot period (from one filter spot change to the next) and this average

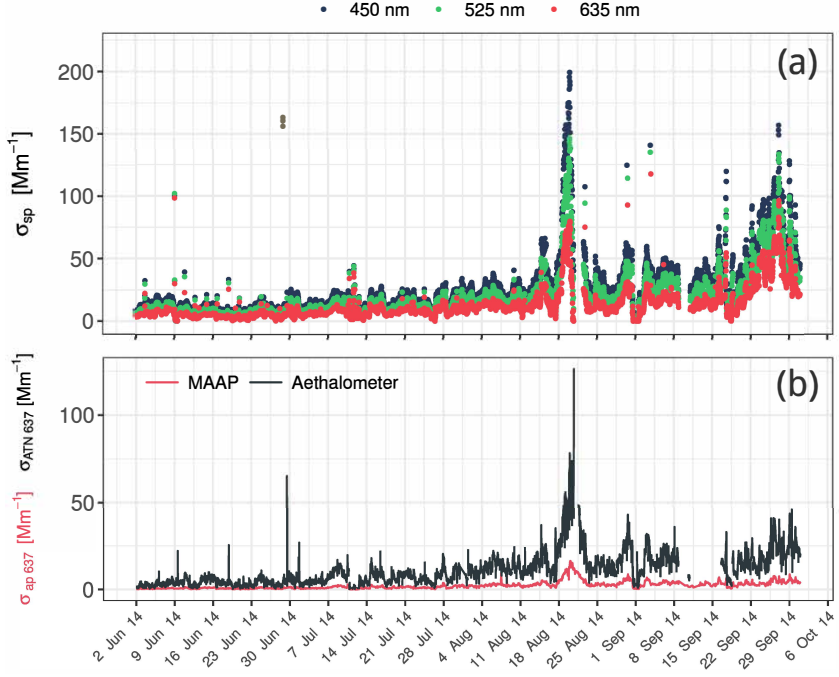

Figure 1. Time series (June-September 2014) of (a) scattering by aerosol particles measured by the nephelometer and (b) Aethalometer attenuation and MAAP absorption coefficient measurements at $637 \mathrm{~nm}$ during the sampling period.

was used for calculating every measurement included in the corresponding filter spot period. The $\omega_{0}$ values at different wavelengths were calculated by using Eq. (12) but including attenuation Ångström exponents $\left(\stackrel{\circ}{a}_{\mathrm{ATN}}\right)$ because $\stackrel{\circ}{a}_{\mathrm{ABS}}$ is not known yet.

Filter-loading corrected data are then divided by the MAAP absorption coefficients to obtain an average $C_{\text {ref }}$. Regarding the embedded aerosol scattering effects, the Collaud Coen correction includes a change in the aerosol scattering effect parameter expressed as $m_{\mathrm{s}}$ in Eq. (11). The constant $m_{\mathrm{s}}$ values used by Schmid et al. (2010) correspond to ammonium sulfate. Collaud Coen substituted them by the measured aerosol scattering properties by using the following equation

$m_{\mathrm{S}}=\beta_{\mathrm{SCA}}^{(d-1)} \cdot c \cdot \lambda^{(-\stackrel{\mathrm{a}}{\mathrm{SCA}}(d-1))}$;

$d=0.564$;

$c=0.00032910\left(\sigma_{\mathrm{sp}}\right.$ in $\mathrm{Mm}^{-1}$ units $)$,

where $\beta_{\mathrm{SCA}}$ is the scattering proportionality constant and $c$ and $d$ are constants corresponding to the power-law relation between $\sigma_{\mathrm{ATN}}$ and $\sigma_{\mathrm{sp}}$, previously reported by Arnott et al. (2005).

Finally, the corrected absorption coefficients are calculated in a similar way to Eq. (5) but using $m_{\mathrm{s}}$ from Eq. (15) and averaging $C_{\text {ref }}, m_{\mathrm{s}}, \omega_{0}$ and $R$ over a filter spot period, i.e., from a filter change time to the subsequent one.

\section{Results and discussion}

The beginning of the sampling period is characterized by low scattering coefficients compared to the second half of the 
period when scattering increases significantly. Several scattering peaks can be observed after the beginning of August (see Fig. 1a). Occasionally, local or regional biomass burning plumes reach the site during the dry season and scattering by aerosol particles increases significantly due to enhanced concentration of fine mode aerosol particles, which are more efficient in scattering light in the visible range. The major effect of multiple-scattering artifacts is evident when comparing MAAP measured absorption coefficients and Aethalometer measured attenuation coefficients (see Fig. 1b). The absorption coefficients averaged $1.8 \pm 2.1 \mathrm{Mm}^{-1}$, with the minimum values occurring in the beginning of the sampling period, whereas a maximum of absorption (up to $15.9 \mathrm{Mm}^{-1}$, measured by MAAP) took place between 18 and $23 \mathrm{Au}-$ gust 2014. Calculated back-trajectories using the HYSPLIT model (Draxler and Hess, 1998) confirmed that air masses on the days of maximum absorption and scattering were coming from south and southeast, an area with intense fire activity; see Fig. S1 in the Supplement. Levoglucosan measurements further confirmed the predominance of biomass-burningoriginated aerosol particles (not shown). From 1 June to 1 August 2014, the attenuation coefficient at $637 \mathrm{~nm}$ had a median of $5.1 \mathrm{Mm}^{-1}$ (3.2-7.9, interquartile range, IQR). Then, during the first days of August, it increased slightly until the biomass burning event took place on 18-23 August 2014. The maximum attenuation coefficient during this event reached $115 \mathrm{Mm}^{-1}$. Details about this event, regarding chemical composition and CCN activity, are presented in Pöhlker et al. (2016, 2017). The observed absorption and attenuation coefficients represent typical conditions at the ATTO site for the wet, transition and dry periods. In the next sections, we present data compensated to account for the different filter artifacts and study the influence of the applied compensation algorithms on the $\stackrel{\circ}{A B S}_{\text {AB }}$. The artifacts that affect the $\stackrel{\circ}{a}_{\mathrm{ABS}}$ retrieval from filter-based multi-wavelength absorption measurements could be avoided by using PAS methods that have been successfully implemented to measure light absorption by suspended aerosol particles (e.g., Ajtai et al., 2010). However, PAS measurements have high detection limits and have only been implemented at near-source measurement sites (Cappa et al., 2012; Cheng et al., 2016; Lewis et al., 2008) and not in clean environments like central Amazonia.

\subsection{Aethalometer corrections}

Immediately after every Aethalometer filter change, aerosol particles are collected on a clean new spot. Under these conditions, the filter-loading effect is considered to be negligible because there is not enough aerosol on the filter to "darken" the substrate (Virkkula et al., 2007). Therefore, the only bias to the Aethalometer response is given by the scattering effects by filter fibers. The scattering by filter fibers, expressed as $C_{\text {ref }}$, was calculated by using Eq. (6), assuming $R \approx 1$ for data corresponding to ATN $<10 \%$. The $C_{\text {ref }}$ time series

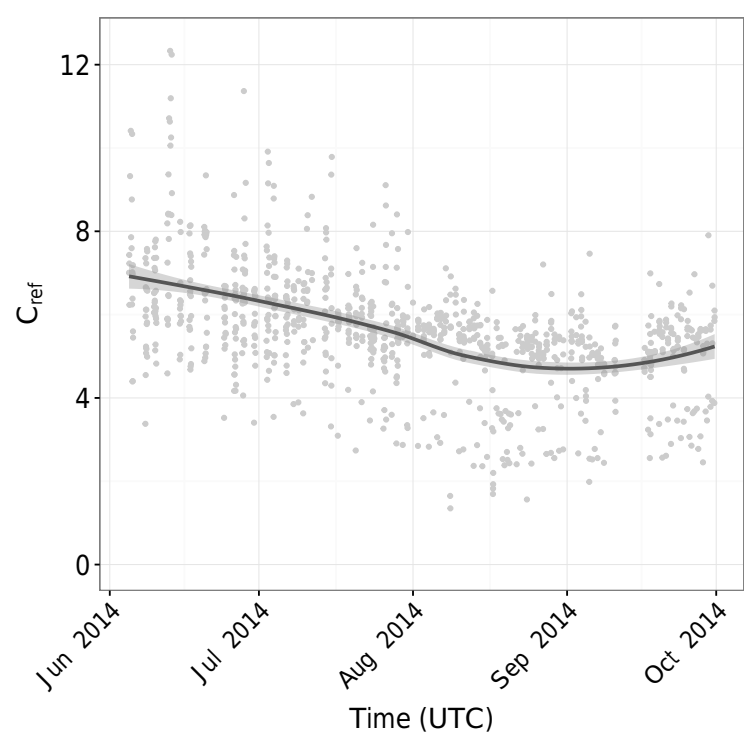

Figure 2. Multiple scattering correction calculated by using MAAP absorption coefficients as reference $(\lambda=637 \mathrm{~nm})$. Light-gray points represent all calculated $C_{\text {ref }}$ values. The black line and shaded area represent a conditional non-parametric mean estimation and its confidence limits, respectively.

is shown in Fig. 2. We observed that $C_{\text {ref }}$ decreased somewhat from June-July to August-September, when the average $\pm 1 \mathrm{SD}$ values were $6.3 \pm 1.5$ and $4.9 \pm 1.1$, respectively. Additionally, we observed a larger $C_{\text {ref }}$ variability during the transition period, which may increase the uncertainty of the corrected absorption coefficients. This seasonal effect on the multiple-scattering compensation parameter could be related to the condensation or adsorption of semi-volatile organic compounds or liquid organic aerosol particles on the filter fibers, inducing a change in the filter matrix optical properties (Collaud Coen et al., 2010; Subramanian et al., 2007; Weingartner et al., 2003). The Schmid algorithm uses an average $C_{\text {ref }}$ for further calculation of the filter-loading correction factor, $R$. We found that using an overall average $C_{\text {ref }}$ significantly affects the calculation of the shadowing factor $(f)$. Therefore, two different averages of $C_{\text {ref }}$ were implemented in this work for the two above-mentioned periods, transition (June-July) and dry season (August-September). Subsequent multiple-scattering correction calculations were conducted using real-time $C_{\text {ref }}$ values.

The measured filter-loading calibration factor $\left(R_{\text {meas }}\right)$ was obtained by using Eq. (9). Then, by following the Schmid algorithm, the shadowing factor was calculated by applying a fit to Eqs. (9) and (10) (Rizzo et al., 2011; Schmid et al., 2006). The calculated average shadowing factors were $1.10 \pm 0.10$ and $1.04 \pm 0.08$ for June-July and AugustSeptember, respectively. These values were lower compared to those obtained for darker aerosols ( $f=1.23-1.89)$ (Weingartner et al., 2003) and for biomass burning aerosol $(f=$ 1.2) (Schmid et al., 2006). At $660 \mathrm{~nm}$, the Aethalometer 
wavelength that is closer to the MAAP measurement wavelength, the filter-loading correction calculation resulted in $R$ correction factors of $0.98 \pm 0.02$ and $1.01 \pm 0.01$ for JuneJuly and August-September, respectively. A slight wavelength dependence was observed; the $R$ values were up to $4 \%$ higher at $370 \mathrm{~nm}$ compared to those calculated at $950 \mathrm{~nm}$ during the cleanest period of this study (June-July). A similar behavior was observed during August-September. As explained by Schmid et al. (2006), this wavelength dependency is related to the fact that $R$ depends on ATN, which increases with decreasing wavelength. The obtained $R$ correction factors were very close to $1-$ i.e., the filter loading effect barely affected the conversion from attenuation to absorption coefficients, even during the most polluted period, AugustSeptember. A filter-loading correction factor close to 1 was expected since the average $\omega_{0}$ measured during the campaign was $0.88 \pm 0.04$ at $637 \mathrm{~nm}$. A high $\omega_{0}$ is related to the predominance of scattering aerosol particles, which diminishes the shadowing effect of dark aerosol particles embedded in the filter matrix (Weingartner et al., 2003).

To compare both correction schemes in terms of the filterloading correction, $C_{\text {ref }}$ was recalculated after compensating all the data for filter loading by (1) following the Schmid et al. correction and (2) the Collaud Coen et al. correction, which includes $\omega_{0}$ in the shadowing factor calculation and the relationship $\sigma_{\mathrm{ATN}}$ vs. ATN. We found no statistical difference between the two correction algorithms in terms of the filter-loading compensation because this effect was generally low over the sampling period. More information about the effect of increasing attenuation on the calculated $C_{\text {ref }}$ after applying the filter-loading correction can be found in the Supplement (Fig. S2).

As already mentioned, the multiple-scattering effects significantly affect the correction of Aethalometer data by a factor of 5 to 7 . According to previous studies, the multiplescattering correction is the most important one in ambient aerosol with a high $\omega_{0}$ (Collaud Coen et al., 2010; Rizzo et al., 2011; Schmid et al., 2006; Segura et al., 2014). The seasonal variability of $C$ can be explained by the different scattering properties of the aerosol particles in the different seasons (Collaud Coen et al., 2010). In order to compare the different scattering contributions to $C$, we calculated $C_{\text {ref }}$ and $C_{\text {sca }}$ by using the Collaud Coen algorithm. $C_{\text {sca }}$ was calculated using Eq. (5) in this case. We observed that a lower $\omega_{0}$ during the biomass burning period was related to a decrease in the scattering correction factor, $C_{\text {sca }}$. The relative contribution of $C_{\text {sca }}$ was examined and it was found that the relative contribution from the scattering correction decreases with decreasing $\omega_{0}$ and increasing $\beta_{\text {sca }}$; see Fig. 3. No correlation was found between $C_{\mathrm{sca}}$ and $\stackrel{a}{\mathrm{SCA}}_{\mathrm{S}}$ since the scattering Ångström exponent was quite stable during the sampling period with the exception of the few days influenced by regional biomass burning (see Fig. S3). In other words, the $C_{\text {sca }}$ relative contribution was only affected by variations on $\beta_{\text {sca }}$ and $\omega_{0}$. Given that $R$ is almost negligible in our dataset, the com-
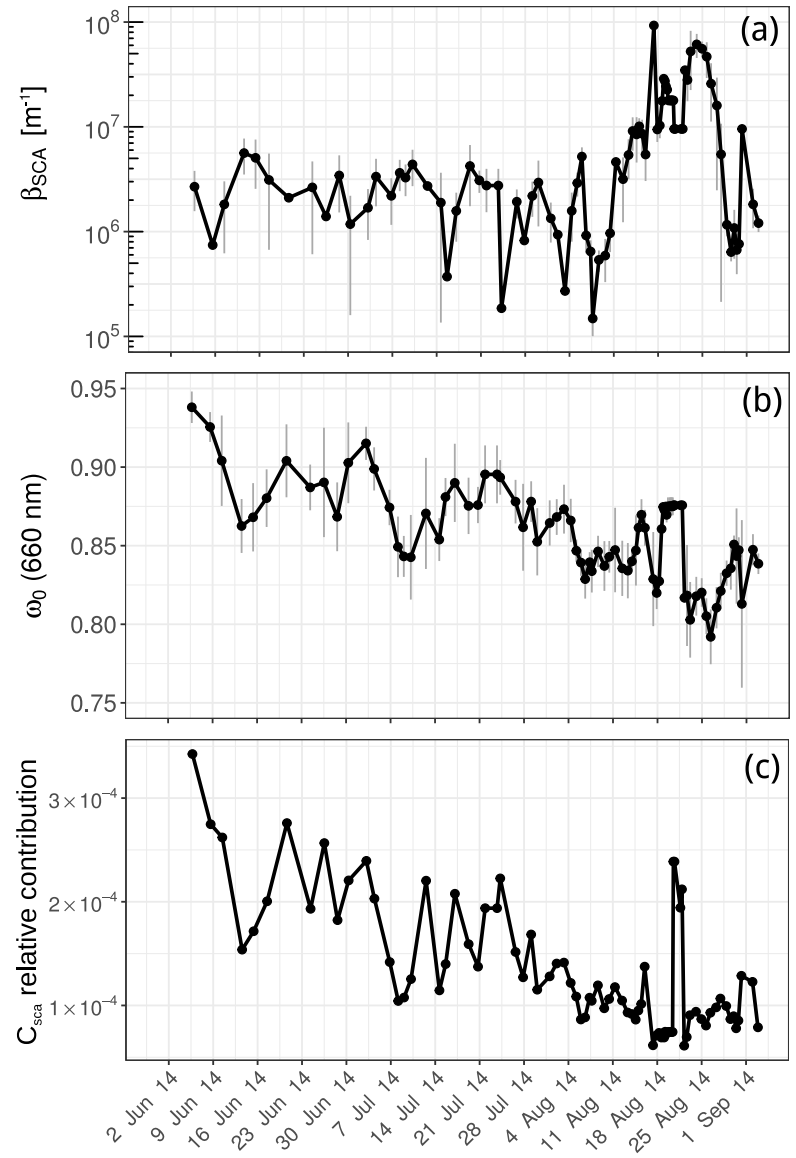

Figure 3. Filter cycle averaged data corresponding to (a) scattering proportionality constant, (b) single-scattering albedo at $660 \mathrm{~nm}$, and (c) relative contribution of $C_{\text {sca }}$ to the total multiple-scattering compensation $\left(C_{\text {ref }}+C_{\text {sca }}\right)$ at $660 \mathrm{~nm}$. Vertical bars in (a) and (b) correspond to 1 standard deviation.

parison between both algorithms was done in terms of their different ways to treat the multiple-scattering effects.

A scatter plot of both corrections' outputs vs. MAAP measurements is shown in Fig. 4. We found that corrected AE data fitted very well the MAAP measurements for both correction algorithms. The slopes were 1.05 (1.04-1.06) and 1.03 (1.02-1.03) for the Schmid and Collaud Coen corrections, respectively, with significant correlation factors. The slight difference between both correction schemes in terms of the comparison to MAAP measurements can be related to the parameterization of $C$ applied by Schmid et al., which is not implemented by Collaud Coen et al., and the way Collaud Coen et al. estimate $C_{\text {ref }}$.

\subsection{Absorption Ångström exponent}

The MWAA was used as a reference multi-wavelength measurement since it accounts for multiple-scattering effects by means of a similar configuration to the MAAP. Light absorp- 


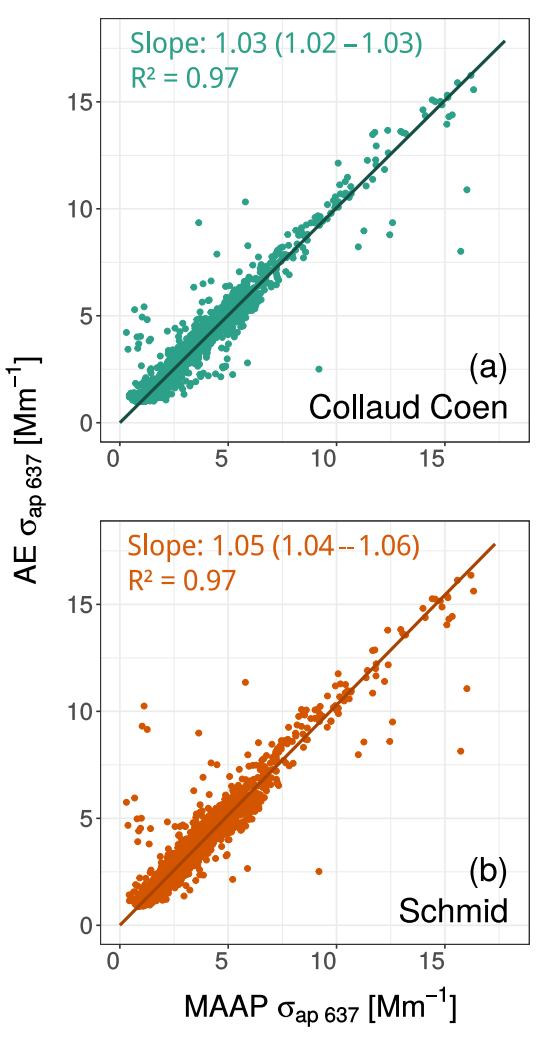

Figure 4. Scatter plot of (a) Collaud Coen and (b) Schmid corrections results vs. MAAP absorption coefficients (all data at $637 \mathrm{~nm}$ ). The fit was obtained by applying a standardized major axis regression.

tion coefficients obtained from the MWAA (at $635 \mathrm{~nm}$ ) and from the MAAP (at $637 \mathrm{~nm}$ ) were compared by applying an linear regression to both datasets after integrating the MAAP data over the filter total sampling times, as shown in Fig. 5. The fit resulted in a MWAA underestimation of 14 to $18 \%$ when fitting the whole dataset. In general, all values measured by the MWAA at $635 \mathrm{~nm}$ were below the MAAP measurements at $637 \mathrm{~nm}$ with a decreasing offset towards lower absorption coefficients. This could be associated with a significant volatilization of the absorbing aerosol collected during the polluted period. The comparison of Aethalometer and MWAA at different wavelengths was based on the assumption that these losses are wavelength-independent.

MWAA data measured at five different wavelengths was used to retrieve $\stackrel{\circ}{A B S}_{\mathrm{ABS}}$ by applying a $\log -\log$ fit as expressed in Eq. (8). Figure 6 shows the MWAA Ångström exponents and their uncertainty intervals, together with the values obtained from the two different Aethalometer corrections and the original $\stackrel{\circ}{\mathrm{ATN}}_{\mathrm{ATN}}$. The MWAA $\stackrel{\circ}{\mathrm{ABS}}_{\mathrm{A}}$ retrieved from each filter were not all statistically optimal; 30 out of 175 had a $R^{2}<0.85$. All the values below this $R^{2}$ limit were excluded from the results shown in Fig. 6. Absorption Ångström exponents obtained using the Schmid correction were mostly

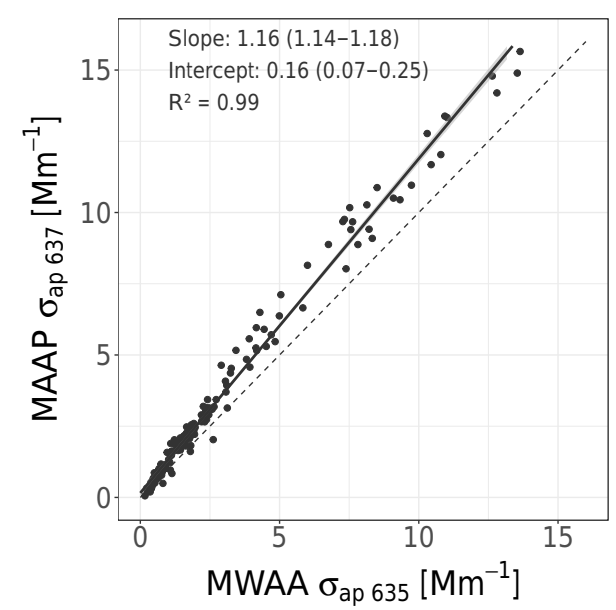

Figure 5. Scatter plot and linear regression of MWAA and MAAP absorption coefficient data. The $1: 1$ relationship is represented by a dashed line. The fit was obtained by applying a standardized major axis regression.

higher than the MWAA results. On the other hand, the Collaud Coen correction resulted in a better approach to reproduce the MWAA data, with most of the results in the MWAA uncertainty range. During the biomass burning period, from 18 to 23 August 2014, the $\mathrm{BrC}$ contribution became more important and caused an increase in the $\stackrel{\circ}{\mathrm{ABS}}_{\mathrm{B}}$ and both algorithms' results became similar to each other and slightly

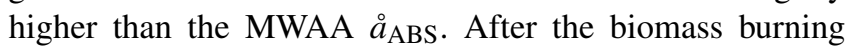
episode, when the scattering and absorption coefficients fell down to background levels, the offset between both algorithms, in terms of $\stackrel{\circ}{A}_{\mathrm{ABS}}$, widened again. In this regard, the Collaud Coen algorithm, which includes a modified scattering correction, seems to be more appropriate to retrieve the $\stackrel{\circ}{a}_{\mathrm{ABS}}$ for a broader range of absorption coefficients.

A scatter plot of the $\stackrel{\circ}{A B S}_{\mathrm{ABS}}$ data, including the corresponding linear fits, is shown in Fig. 7. The data analyzed in this comparison include only filters that had a $\sigma_{\text {ap }}$ vs. $\lambda \log -$ $\log$ fit with $R^{2}>0.85$. Although both algorithms overestimate the $\stackrel{\circ}{a}_{\mathrm{ABS}}$ retrieved from the MWAA measurements, the Collaud Coen algorithm produces a lower offset and a better linear fit, with a $R^{2}=0.72$. On the other hand, the Schmid algorithm seems to be artificially enhancing the absorption at lower wavelengths. When applying linear regressions forced through the origin, the overall tendency showed a statistically significant $\stackrel{\circ}{A B S}_{\text {overestimation by the Schmid }}$ algorithm and a better fit for the Collaud Coen algorithm (not shown). The original attenuation Ångström exponent $\left(\stackrel{\circ}{a}_{\mathrm{ATN}}\right.$, without applying any compensation) was also found to fit the MWAA-retrieved $\stackrel{\circ}{a}_{\text {ABS }}$ quite well (slope IQR: 0.89 1.10 with $R^{2}=0.75$, not shown). This finding is in accordance with Ajtai et al. (2011), who found a good agreement between $4 \lambda$ PAS measurements and the Aethalometer raw wavelength dependence at a suburban site. 


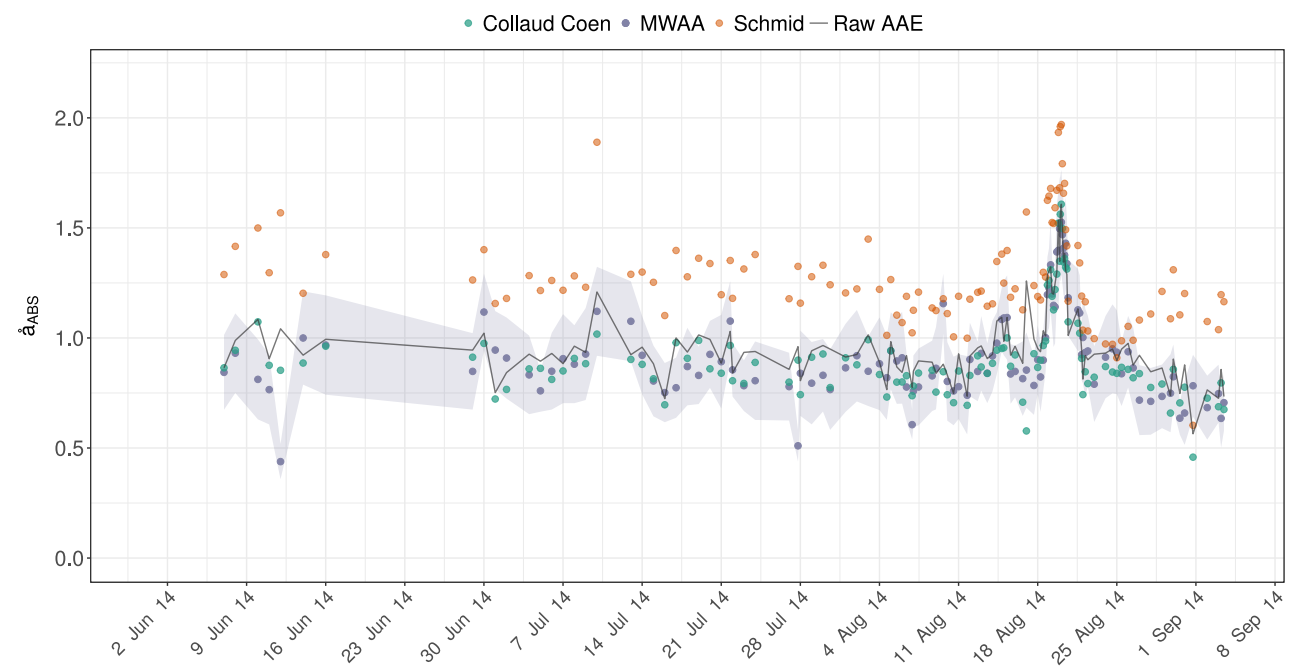

Figure 6. Wavelength dependence retrieved from MWAA absorption data and its standard error (purple points and shaded area), raw attenuation data (gray line), and Schmid (orange points) and Collaud Coen (green points) corrected absorption data, all averaged over MWAA sample intervals. Error lines were removed to improve visualization.

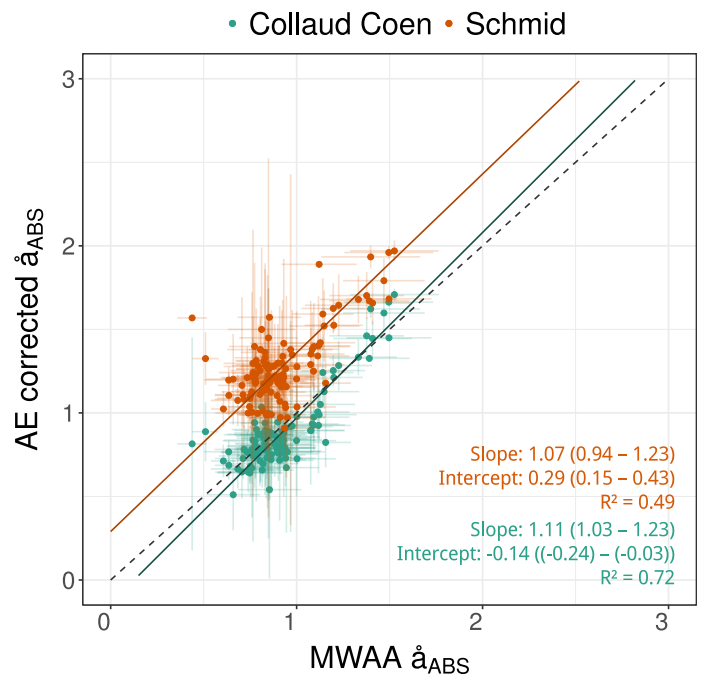

Figure 7. Scatter plot of AAE values obtained by Aethalometer corrections vs. AAE obtained from MWAA measurements. The darkcolored lines correspond to the standardized major axis linear fits and light-colored lines correspond to 1 standard deviation of the retrieved AAE data. The dashed gray line represents a $1: 1$ relationship.

\subsection{Overestimation of near-UV absorption by AE corrections}

The unexpectedly high $\stackrel{\circ}{A B S}_{\text {, }}$, especially that obtained by applying the Schmid algorithm, is probably caused by an artificial enhancement of the near-UV absorption. Figure 8 shows the relative enhancement of the absorption coefficients at $370 \mathrm{~nm}$, compared to the MWAA absorption at $375 \mathrm{~nm}$. No

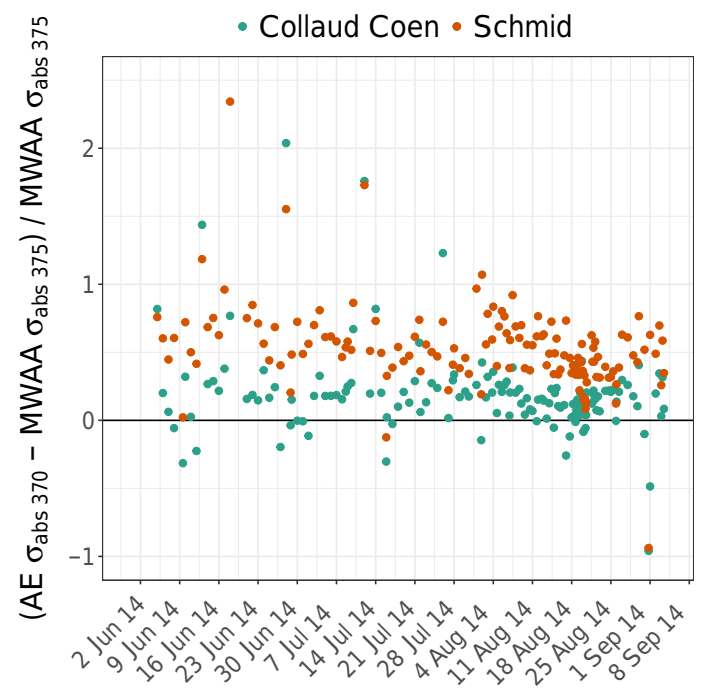

Figure 8. Overestimation of Aethalometer corrected absorption coefficients relative to MWAA at $370 \mathrm{~nm}$. Values above zero are related to an overestimation of $\sigma_{\text {ap }}$ and, below zero, to an underestimation of $\sigma_{\text {ap }}$ at this given wavelength.

interpolation was applied to match both wavelengths since they are close enough that the differences were negligible ( $\sim 3 \%$ for a $\stackrel{\circ}{A B S}_{\mathrm{AB}}$ of 2.0 ). It is clear that the Schmid algorithm almost always overestimated the absorption at $370 \mathrm{~nm}$. Only a few filters showed a difference close to or below zero. On average, the Schmid algorithm overestimation relative to MWAA was a factor of $0.46 \pm 0.31$. In the case of the Collaud Coen algorithm, the average difference was slightly positive, being a factor of $0.19 \pm 0.32$, and reaching an average of $0.12 \pm 0.12$ for $\sigma_{\mathrm{ap}}>5 \mathrm{Mm}^{-1}$, during the biomass burn- 
ing event. A near-UV over- or underestimation of the data will substantially affect brown carbon calculations if apportionment algorithms based on the wavelength dependence of absorption are used. More details on the effects of inaccurate $\stackrel{\circ}{\mathrm{ABS}}_{\mathrm{A}}$ on the $\mathrm{BrC} / \mathrm{BC}$ apportionment are discussed in Garg et al. (2016), Schuster et al. (2016a, b), Wang et al. (2016), and references therein. A BrC estimation is beyond the scope of this paper.

\section{Conclusions}

We applied two different correction algorithms to compensate for the various Aethalometer absorption measurement artifacts. The compensated data were compared to an offline multi-wavelength reference absorption measurement technique. This comparison allowed studying the effects of the correction schemes on the absorption at lower wavelengths and showed how this affects the $\stackrel{\circ}{A B S}_{\text {retrieval. We found }}$ that both analyzed algorithms efficiently reproduce the reference MAAP absorption coefficients from Aethalometer data. However, the Schmid algorithm overestimates the $\stackrel{\circ}{A B S}_{\mathrm{AB}}$ compared to that obtained by the multiple wavelength measurement (MWAA). On the other hand, the Collaud Coen algorithm as well as the "raw" Aethalometer attenuation spectral dependence reproduced the $\stackrel{\circ}{\mathrm{ABS}}_{\mathrm{AB}}$ values obtained from MWAA measurements quite well. The under- or overestimation of short-wavelength absorption coefficients by compensation algorithms is a factor that has to be considered when using corrected Aethalometer data to apportion the black and brown carbon contributions to total absorption. When comparing the absorption coefficients obtained from the different correction algorithms to the reference measurement at $370 \mathrm{~nm}$, we found that the Collaud Coen algorithm is more appropriate to achieve the best comparison at this wavelength, especially for data with $\sigma_{\mathrm{ap}}>5 \mathrm{Mm}^{-1}$. The Schmid algorithm resulted in high enhancements of the absorption coefficients at $370 \mathrm{~nm}$ over the sampling period.

Data availability. The data presented in this paper can be accessed via e-mail request to Jorge Saturno (j.saturno@mpic.de).

\section{The Supplement related to this article is available online at https://doi.org/10.5194/amt-10-2837-2017-supplement.}

Competing interests. The authors declare that they have no conflict of interest.

Acknowledgements. This work has been supported by the Max Planck Society (MPG) and the Max Planck Graduate School
(MPGS). For the operation of the ATTO site, we acknowledge the support by the German Federal Ministry of Education and Research (BMBF contract 01LB1001A) and the Brazilian Ministério da Ciência, Tecnologia e Inovação (MCTI/FINEP contract 01.11.01248.00) as well as the Amazon State University (UEA), FAPEAM, LBA/INPA and SDS/CEUC/RDS-Uatumã. Paulo Artaxo acknowledges support from FAPESP - Fundação de Amparo à Pesquisa do Estado de São Paulo. Jorge Saturno is grateful for a PhD scholarship from the Fundación Gran Mariscal de Ayacucho (Fundayacucho). We acknowledge Paola Fermo, Raquel Gonzalez and Lorenza Corbella for the levoglucosan analysis. This paper contains results of research conducted under the Technical/Scientific Cooperation Agreement between the National Institute for Amazonian Research, the State University of Amazonas, and the Max-Planck-Gesellschaft e.V.; the opinions expressed are the entire responsibility of the authors and not of the participating institutions. We highly acknowledge the support by the Instituto Nacional de Pesquisas da Amazônia (INPA). We would like to especially thank all the people involved in the technical, logistical, and scientific support of the ATTO project, in particular Reiner Ditz, Jürgen Kesselmeier, Niro Higuchi, Matthias Sörgel, Stefan Wolff, Thomas Disper, Andrew Crozier, Uwe Schulz, Steffen Schmidt, Antonio Ocimar Manzi, Alcides Camargo Ribeiro, Hermes Braga Xavier, Elton Mendes da Silva, Nagib Alberto de Castro Souza, Adi Vasconcelos Brandão, Amaury Rodrigues Pereira, Antonio Huxley Melo Nascimento, Thiago de Lima Xavier, Josué Ferreira de Souza, Roberta Pereira de Souza, Bruno Takeshi, Ana María Yáñez-Serrano and Wallace Rabelo Costa. Moreover, we thank Thorsten Hoffmann, Ulrich Pöschl, Arthur Sedlacek, Jeannine Ditas, Su Hang, Jian Wang, Sachin Gunthe, Jan-David Förster, Ming Jing, Tobias Könemann, Maria Praß, Andrea Arangio and Bruna Amorim Holanda for support and stimulating discussions.

The authors gratefully acknowledge the NOAA Air Resources Laboratory (ARL) for the provision of the HYSPLIT transport and dispersion model and READY website (http://www.ready.noaa.gov) used in this publication.

The article processing charges for this open-access publication were covered by the Max Planck Society.

Edited by: Paolo Laj

Reviewed by: two anonymous referees

\section{References}

Ajtai, T., Filep, Á., Schnaiter, M., Linke, C., Vragel, M., Bozóki, Z., Szabó, G., and Leisner, T.: A novel multi-wavelength photoacoustic spectrometer for the measurement of the UV-vis-NIR spectral absorption coefficient of atmospheric aerosols, J. Aerosol Sci., 41, 1020-1029, https://doi.org/10.1016/j.jaerosci.2010.07.008, 2010.

Ajtai, T., Filep, Á., Utry, N., Schnaiter, M., Linke, C., Bozóki, Z., Szabó, G., and Leisner, T.: Inter-comparison of optical absorption coefficients of atmospheric aerosols determined by a multiwavelength photoacoustic spectrometer and an Aethalometer under sub-urban wintry conditions, J. Aerosol Sci., 42, 859-866, https://doi.org/10.1016/j.jaerosci.2011.07.008, 2011. 
Andreae, M. O. and Gelencsér, A.: Black carbon or brown carbon? The nature of light-absorbing carbonaceous aerosols, Atmos. Chem. Phys., 6, 3131-3148, https://doi.org/10.5194/acp-63131-2006, 2006.

Andreae, M. O. and Ramanathan, V.: Climate's Dark Forcings, Science, 340, 280-281, https://doi.org/10.1126/science.1235731, 2013.

Andreae, M. O., Acevedo, O. C., Araùjo, A., Artaxo, P., Barbosa, C. G. G., Barbosa, H. M. J., Brito, J., Carbone, S., Chi, X., Cintra, B. B. L., da Silva, N. F., Dias, N. L., Dias-Júnior, C. Q., Ditas, F., Ditz, R., Godoi, A. F. L., Godoi, R. H. M., Heimann, M., Hoffmann, T., Kesselmeier, J., Könemann, T., Krüger, M. L., Lavrič, J. V, Manzi, A. O., Lopes, A. P., Martins, D. L., Mikhailov, E. F., Moran-Zuloaga, D., Nelson, B. W., Nölscher, A. C., Santos Nogueira, D., Piedade, M. T. F., Pöhlker, C., Pöschl, U., Quesada, C. A., Rizzo, L. V, Ro, C.-U., Ruckteschler, N., Sá, L. D. A., de Oliveira Sá, M., Sales, C. B., dos Santos, R. M. N., Saturno, J., Schöngart, J., Sörgel, M., de Souza, C. M., de Souza, R. A. F., Su, H., Targhetta, N., Tóta, J., Trebs, I., Trumbore, S., van Eijck, A., Walter, D., Wang, Z., Weber, B., Williams, J., Winderlich, J., Wittmann, F., Wolff, S., and Yáñez-Serrano, A. M.: The Amazon Tall Tower Observatory (ATTO): overview of pilot measurements on ecosystem ecology, meteorology, trace gases, and aerosols, Atmos. Chem. Phys., 15, 10723-10776, https://doi.org/10.5194/acp-15-10723-2015, 2015.

Ångström, A.: On the Atmospheric Transmission of Sun Radiation and on Dust in the Air, Geogr. Ann., 11, 156-166, 1929.

Arnott, W. P., Hamasha, K., Moosmüller, H., Sheridan, P. J., and Ogren, J. A.: Towards Aerosol Light-Absorption Measurements with a 7-Wavelength Aethalometer: Evaluation with a Photoacoustic Instrument and 3Wavelength Nephelometer, Aerosol Sci. Technol., 39, 17-29, https://doi.org/10.1080/027868290901972, 2005.

Bergstrom, R. W., Russell, P. B., and Hignett, P.: Wavelength Dependence of the Absorption of Black Carbon Particles?: Predictions and Results from the TARFOX Experiment and Implications for the Aerosol Single Scattering Albedo, J. Atmos. Sci., 59, 567-577, 2002.

Bond, T. C. and Bergstrom, R. W.: Light Absorption by Carbonaceous Particles?: An Investigative Review, Aerosol Sci. Technol., 40, 27-67, https://doi.org/10.1080/02786820500421521, 2006.

Bond, T. C., Doherty, S. J., Fahey, D. W., Forster, P. M., Berntsen, T., DeAngelo, B. J., Flanner, M. G., Ghan, S., Kärcher, B., Koch, D., Kinne, S., Kondo, Y., Quinn, P. K., Sarofim, M. C., Schultz, M. G., Schulz, M., Venkataraman, C., Zhang, H., Zhang, S., Bellouin, N., Guttikunda, S. K., Hopke, P. K., Jacobson, M. Z., Kaiser, J. W., Klimont, Z., Lohmann, U., Schwarz, J. P., Shindell, D., Storelvmo, T., Warren, S. G., and Zender, C. S.: Bounding the role of black carbon in the climate system: A scientific assessment, J. Geophys. Res.-Atmos., 118, 5380-5552, https://doi.org/10.1002/jgrd.50171, 2013.

Cappa, C. D., Onasch, T. B., Massoli, P., Worsnop, D. R., Bates, T. S., Cross, E. S., Davidovits, P., Hakala, J., Hayden, K. L., Jobson, B. T., Kolesar, K. R., Lack, D. a, Lerner, B. M., Li, S.-M., Mellon, D., Nuaaman, I., Olfert, J. S., Petäjä, T., Quinn, P. K., Song, C., Subramanian, R., Williams, E. J., and Zaveri, R. A.: Radiative absorption enhancements due to the mixing state of atmospheric black carbon, Science, 337, 1078-1081, https://doi.org/10.1126/science.1223447, 2012.
Cheng, Y., Engling, G., Moosmüller, H., Arnott, W. P., Chen, A. L. W., Wold, C. E., Hao, W. M., and He, K.: Light absorption by biomass burning source emissions, Atmos. Environ., 127, 347354, https://doi.org/10.1016/j.atmosenv.2015.12.045, 2016.

Collaud Coen, M., Weingartner, E., Apituley, A., Ceburnis, D., Fierz-Schmidhauser, R., Flentje, H., Henzing, J. S., Jennings, S. G., Moerman, M., Petzold, A., Schmid, O., and Baltensperger, U.: Minimizing light absorption measurement artifacts of the Aethalometer: evaluation of five correction algorithms, Atmos. Meas. Tech., 3, 457-474, https://doi.org/10.5194/amt-3-4572010, 2010.

Després, V. R., Alex Huffman, J., Burrows, S. M., Hoose, C., Safatov, A. S., Buryak, G., Fröhlich-Nowoisky, J., Elbert, W., Andreae, M. O., Pöschl, U., and Jaenicke, R.: Primary biological aerosol particles in the atmosphere: a review, Tellus B, 64, 15598, https://doi.org/10.3402/tellusb.v64i0.15598, 2012.

Draxler, R. R. and Hess, G. D.: An overview of the HYSPLIT 4 modelling system for trajectories, dispersion and deposition, Aust. Met. Mag., 47, 295-308, 1998.

Drinovec, L., Močnik, G., Zotter, P., Prévôt, A. S. H., Ruckstuhl, C., Coz, E., Rupakheti, M., Sciare, J., Müller, T., Wiedensohler, A., and Hansen, A. D. A.: The "dual-spot" Aethalometer: an improved measurement of aerosol black carbon with realtime loading compensation, Atmos. Meas. Tech., 8, 1965-1979, https://doi.org/10.5194/amt-8-1965-2015, 2015.

Favez, O., El Haddad, I., Piot, C., Boréave, A., Abidi, E., Marchand, N., Jaffrezo, J.-L., Besombes, J.-L., Personnaz, M.-B., Sciare, J., Wortham, H., George, C., and D'Anna, B.: Intercomparison of source apportionment models for the estimation of wood burning aerosols during wintertime in an Alpine city (Grenoble, France), Atmos. Chem. Phys., 10, 5295-5314, https://doi.org/10.5194/acp-10-5295-2010, 2010.

Flowers, B. A., Dubey, M. K., Mazzoleni, C., Stone, E. A., Schauer, J. J., Kim, S.-W., and Yoon, S. C.: Optical-chemicalmicrophysical relationships and closure studies for mixed carbonaceous aerosols observed at Jeju Island; 3-laser photoacoustic spectrometer, particle sizing, and filter analysis, Atmos. Chem. Phys., 10, 10387-10398, https://doi.org/10.5194/acp-10-103872010, 2010.

Garg, S., Chandra, B. P., Sinha, V., Sarda-Esteve, R., Gros, V., and Sinha, B.: Limitation of the Use of the Absorption Angstrom Exponent for Source Apportionment of Equivalent Black Carbon: a Case Study from the North West Indo-Gangetic Plain, Environ. Sci. Technol., 50, 814-824, https://doi.org/10.1021/acs.est.5b03868, 2016.

Hansen, A. D. A., Rosen, H., and Novakov, T.: The aethalometer - An instrument for the real-time measurement of optical absorption by aerosol particles, Sci. Total Environ., 36, 191-196, https://doi.org/10.1016/0048-9697(84)90265-1, 1984.

Hyvärinen, A.-P., Vakkari, V., Laakso, L., Hooda, R. K., Sharma, V. P., Panwar, T. S., Beukes, J. P., van Zyl, P. G., Josipovic, M., Garland, R. M., Andreae, M. O., Pöschl, U., and Petzold, A.: Correction for a measurement artifact of the MultiAngle Absorption Photometer (MAAP) at high black carbon mass concentration levels, Atmos. Meas. Tech., 6, 81-90, https://doi.org/10.5194/amt-6-81-2013, 2013.

IPCC: Climate Change 2013: The Physical Science Basis. Contribution of Working Group I to the Fifth Assessment Report of the 
Intergovernmental Panel on Climate Change, Cambridge, UK, 1535 pp., 2013.

Kirchstetter, T. W., Novakov, T., and Hobbs, P. V.: Evidence that the spectral dependence of light absorption by aerosols is affected by organic carbon, J. Geophys. Res.-Atmos., 109, D21208, https://doi.org/10.1029/2004JD004999, 2004.

Lack, D. A. and Cappa, C. D.: Impact of brown and clear carbon on light absorption enhancement, single scatter albedo and absorption wavelength dependence of black carbon, Atmos. Chem. Phys., 10, 4207-4220, https://doi.org/10.5194/acp10-4207-2010, 2010.

Lack, D. A. and Langridge, J. M.: On the attribution of black and brown carbon light absorption using the Ångström exponent, Atmos. Chem. Phys., 13, 10535-10543, https://doi.org/10.5194/acp-13-10535-2013, 2013.

Laskin, A., Laskin, J., and Nizkorodov, S. A.: Chemistry of Atmospheric Brown Carbon, Chem. Rev., 115, 4335-4382, https://doi.org/10.1021/cr5006167, 2015.

Lewis, K., Arnott, W. P., Moosmüller, H., and Wold, C. E.: Strong spectral variation of biomass smoke light absorption and single scattering albedo observed with a novel dual-wavelength photoacoustic instrument, J. Geophys. Res., 113, D16203, https://doi.org/10.1029/2007JD009699, 2008.

Massabò, D., Bernardoni, V., Bove, M. C., Brunengo, A., Cuccia, E., Piazzalunga, A., Prati, P., Valli, G., and Vecchi, R.: A multi-wavelength optical set-up for the characterization of carbonaceous particulate matter, J. Aerosol Sci., 60, 34-46, https://doi.org/10.1016/j.jaerosci.2013.02.006, 2013.

Massabò, D., Caponi, L., Bernardoni, V., Bove, M. C., Brotto, P., Calzolai, G., Cassola, F., Chiari, M., Fedi, M. E., Fermo, P., Giannoni, M., Lucarelli, F., Nava, S., Piazzalunga, A., Valli, G., Vecchi, R., and Prati, P.: Multi-wavelength optical determination of black and brown carbon in atmospheric aerosols, Atmos. Environ., 108, 1-12, https://doi.org/10.1016/j.atmosenv.2015.02.058, 2015.

Moosmüller, H., Chakrabarty, R. K., Ehlers, K. M., and Arnott, W. P.: Absorption Ångström coefficient, brown carbon, and aerosols: basic concepts, bulk matter, and spherical particles, Atmos. Chem. Phys., 11, 1217-1225, https://doi.org/10.5194/acp11-1217-2011, 2011.

Müller, T., Laborde, M., Kassell, G., and Wiedensohler, A.: Design and performance of a three-wavelength LED-based total scatter and backscatter integrating nephelometer, Atmos. Meas. Tech., 4, 1291-1303, https://doi.org/10.5194/amt-4-1291-2011, 2011.

Myhre, G. and Stordal, F.: Global sensitivity experiments of the radiative forcing due to mineral aerosols, J. Geophys. Res.-Atmos., 106, 18193-18204, https://doi.org/10.1029/2000JD900536, 2001.

Penner, J. E., Dickinson, R. E., and O'Neill, C. A.: Effects of Aerosol from Biomass Burning on the Global Radiation Budget, Science, 256, 1432-1434, https://doi.org/10.1126/science.256.5062.1432, 1992.

Petzold, A. and Schönlinner, M.: Multi-angle absorption photometry - a new method for the measurement of aerosol light absorption and atmospheric black carbon, J. Aerosol Sci., 35, 421-441, https://doi.org/10.1016/j.jaerosci.2003.09.005, 2004.

Petzold, A., Schloesser, H., Sheridan, P. J., Arnott, W. P., Ogren, J. A., and Virkkula, A.: Evaluation of Multiangle Absorption Photometry for Measuring Aerosol Light Absorption, Aerosol Sci.
Technol., 39, 40-51, https://doi.org/10.1080/027868290901945, 2005.

Pöhlker, M. L., Pöhlker, C., Klimach, T., Hrabe de Angelis, I., Barbosa, H. M. J., Brito, J., Carbone, S., Cheng, Y., Chi, X., Ditas, F., Ditz, R., Gunthe, S. S., Kesselmeier, J., Könemann, T., Lavrič, J. V., Martin, S. T., Moran-Zuloaga, D., Rose, D., Saturno, J., Su, H., Thalman, R., Walter, D., Wang, J., Wolff, S., Artaxo, P., Andreae, M. O. and Pöschl, U.: Long-term observations of cloud condensation nuclei in the Amazon rain forest - Part 1: Aerosol size distribution, hygroscopicity, and new model parametrizations for CCN prediction, Atmos. Chem. Phys., 16, 1570915740, https://doi.org/10.5194/acp-16-15709-2016, 2016.

Pöhlker, M. L., Pöhlker, C., Klimach, T., Hrabe de Angelis, I., Barbosa, H. M. J., Brito, J., Carbone, S., Chi, X., Cheng, Y., Ditas, F., Ditz, R., Gunthe, S. S., Kesselmeier, J., Könemann, T., Lavrič, J. V., Martin, S. T., Moran-Zuloaga, D., Rose, D., Saturno, J., Su, H., Thalman, R., Walter, D., Wang, J., Wolff, S., Artaxo, P., Andreae, M. O., and Pöschl, U.: Long-term observations of atmospheric aerosol, cloud condensation nuclei concentration and hygroscopicity in the Amazon rain forest - Part 2: Ultrafine particle bursts, biomass burning and long range transport events, Atmos. Chem. Phys., in preparation, 2017.

Rizzo, L. V., Correia, A. L., Artaxo, P., Procópio, A. S., and Andreae, M. O.: Spectral dependence of aerosol light absorption over the Amazon Basin, Atmos. Chem. Phys., 11, 8899-8912, https://doi.org/10.5194/acp-11-8899-2011, 2011.

Saleh, R., Robinson, E. S., Tkacik, D. S., Ahern, A. T., Liu, S., Aiken, A. C., Sullivan, R. C., Presto, A. a, Dubey, M. K., Yokelson, R. J., Donahue, N. M., and Robinson, A. L.: Brownness of organics in aerosols from biomass burning linked to their black carbon content, Nat. Geosci., 7, 2-5, https://doi.org/10.1038/ngeo2220, 2014.

Sandradewi, J., Prévôt, A. S. H., Szidat, S., Perron, N., Alfarra, M. R., Lanz, V. A., Weingartner, E., and Baltensperger, U.: Using aerosol light absorption measurements for the quantitative determination of wood burning and traffic emission contributions to particulate matter, Environ. Sci. Technol., 42, 3316-23, 2008.

Schmid, O., Artaxo, P., Arnott, W. P., Chand, D., Gatti, L. V., Frank, G. P., Hoffer, A., Schnaiter, M., and Andreae, M. O.: Spectral light absorption by ambient aerosols influenced by biomass burning in the Amazon Basin. I: Comparison and field calibration of absorption measurement techniques, Atmos. Chem. Phys., 6, 3443-3462, https://doi.org/10.5194/acp-6-3443-2006, 2006.

Schuster, G. L., Dubovik, O., and Arola, A.: Remote sensing of soot carbon - Part 1: Distinguishing different absorbing aerosol species, Atmos. Chem. Phys., 16, 1565-1585, https://doi.org/10.5194/acp-16-1565-2016, 2016a.

Schuster, G. L., Dubovik, O., Arola, A., Eck, T. F., and Holben, B. N.: Remote sensing of soot carbon - Part 2: Understanding the absorption Ångström exponent, Atmos. Chem. Phys., 16, 15871602, https://doi.org/10.5194/acp-16-1587-2016, 2016b.

Segura, S., Estellés, V., Titos, G., Lyamani, H., Utrillas, M. P., Zotter, P., Prévôt, A. S. H., Močnik, G., Alados-Arboledas, L., and Martínez-Lozano, J. A.: Determination and analysis of in situ spectral aerosol optical properties by a multiinstrumental approach, Atmos. Meas. Tech., 7, 2373-2387, https://doi.org/10.5194/amt-7-2373-2014, 2014.

Subramanian, R., Roden, C. A., Boparai, P., and Bond, T. C.: Yellow Beads and Missing Particles: Trouble Ahead for Filter-Based 
Absorption Measurements, Aerosol Sci. Technol., 41, 630-637, https://doi.org/10.1080/02786820701344589, 2007.

Virkkula, A.: Correction of the Calibration of the 3wavelength Particle Soot Absorption Photometer

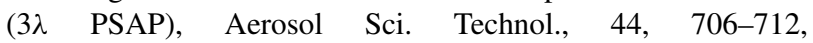
https://doi.org/10.1080/02786826.2010.482110, 2010.

Virkkula, A., Ahlquist, N. C., Covert, D. S., Arnott, W. P., Sheridan, P. J., Quinn, P. K., and Coffman, D. J.: Modification, Calibration and a Field Test of an Instrument for Measuring Light Absorption by Particles, Aerosol Sci. Technol., 39, 68-83, https://doi.org/10.1080/027868290901963, 2005.

Virkkula, A., Mäkelä, T., Hillamo, R., Yli-Tuomi, T., Hirsikko, A., Hämeri, K., and Koponen, I. K.: A simple procedure for correcting loading effects of aethalometer data, J. Air Waste Manag. Assoc., 57, 1214-1222, https://doi.org/10.3155/10473289.57.10.1214, 2007.

Wang, X., Heald, C. L., Sedlacek, A. J., de Sá, S. S., Martin, S. T., Alexander, M. L., Watson, T. B., Aiken, A. C., Springston, S. R., and Artaxo, P.: Deriving brown carbon from multiwavelength absorption measurements: method and application to AERONET and Aethalometer observations, Atmos. Chem. Phys., 16, 1273312752, https://doi.org/10.5194/acp-16-12733-2016, 2016.
Weingartner, E., Saathoff, H., Schnaiter, M., Streit, N., Bitnar, B., and Baltensperger, U.: Absorption of light by soot particles: determination of the absorption coefficient by means of aethalometers, J. Aerosol Sci., 34, 1445-1463, https://doi.org/10.1016/S0021-8502(03)00359-8, 2003.

Yu, H., Kaufman, Y. J., Chin, M., Feingold, G., Remer, L. A., Anderson, T. L., Balkanski, Y., Bellouin, N., Boucher, O., Christopher, S., DeCola, P., Kahn, R., Koch, D., Loeb, N., Reddy, M. S., Schulz, M., Takemura, T., and Zhou, M.: A review of measurement-based assessments of the aerosol direct radiative effect and forcing, Atmos. Chem. Phys., 6, 613-666, https://doi.org/10.5194/acp-6-613-2006, 2006. 